\title{
Marihabitans asiaticum gen. nov., sp. nov., a meso- diaminopimelic acid-containing member of the family Intrasporangiaceae
}

Correspondence
Yoko Takahashi
ytakaha@lisci.kitasato-u.ac.jp

\author{
Akiko Kageyama, ${ }^{1}$ Tomomi Haga, ${ }^{2}$ Hiroaki Kasai, ${ }^{2}$ Yoshikazu Shizuri, ${ }^{2}$ \\ Satoshi Ōmura ${ }^{1,3}$ and Yoko Takahashi ${ }^{1}$ \\ ${ }^{1}$ Kitasato Institute for Life Sciences, Kitasato University, 5-9-1 Shirokane, Minato-ku, Tokyo 108- \\ 8642, Japan \\ ${ }^{2}$ Marine Biotechnology Institute, 3-75-1 Heita, Kamaishi, Iwate 026-0001, Japan \\ ${ }^{3}$ The Kitasato Institute, 5-9-1 Shirokane, Minato-ku, Tokyo 108-8642, Japan
}

Strain $\mathrm{HG} 667^{\top}$, isolated from surface seawater collected at the Kesennuma ferry port in Miyagi Prefecture, Japan, was found to be a Gram-positive, catalase-positive bacterium comprising irregular short rods and cocci. The diagnostic diamino acid in the cell-wall peptidoglycan was meso-diaminopimelic acid. The major menaquinone was MK-8 $\left(\mathrm{H}_{4}\right)$. Mycolic acids were not detected. The $\mathrm{G}+\mathrm{C}$ content of the DNA was 70 mol\%. Analysis of the $16 \mathrm{~S}$ rRNA gene sequence revealed that the strain represents a novel lineage within the family Intrasporangiaceae, order Actinomycetales, being associated with the genus Kribbia. On the basis of morphological, biochemical and chemotaxonomic properties of the strain, together with phylogenetic data relating to the $16 \mathrm{~S}$ rRNA gene sequence, $\mathrm{HG}_{6} 67^{\top}$ represents a novel genus and species in the family Intrasporangiaceae, for which the name Marihabitans asiaticum gen. nov., sp. nov. is proposed. The type strain of Marihabitans asiaticum is $\mathrm{HG} 67^{\top}\left(=\mathrm{MBIC0} 07497^{\top}=\mathrm{DSM} 18935^{\top}\right)$.
The family Intrasporangiaceae was proposed by Rainey et al. (in Stackebrandt et al., 1997) and its description was emended by Stackebrandt \& Schumann (2000). The genera belonging to this family can be divided into three groups on the basis of the diagnostic diamino acid types in the cell-wall peptidoglycan: the LL-diaminopimelic acid (LL$\left.\mathrm{A}_{2} \mathrm{pm}\right)$ type, the meso- $\mathrm{A}_{2} \mathrm{pm}$ type and the L-ornithine type. The genera Janibacter (Martin et al., 1997), Knoellia (Groth et al., 2002), Kribbia (Jung et al., 2006), Oryzihumus (Kageyama et al., 2005), Phycicoccus (Lee, 2006) and Tetrasphaera (Maszenan et al., 2000) belong to the meso$\mathrm{A}_{2} \mathrm{pm}$ group. The strain described in the present study, HG667 ${ }^{\mathrm{T}}$, also contained meso- $\mathrm{A}_{2} \mathrm{pm}$ as the diagnostic diamino acid in the cell-wall peptidoglycan.

Strain $\mathrm{HG}_{6} 7^{\mathrm{T}}$ was isolated from surface seawater collected in November 2003 at the Kesennuma ferry port in Miyagi Prefecture, Japan (GPS location: $38^{\circ} 53^{\prime} 52^{\prime \prime}$ N $141^{\circ} 35^{\prime} 35^{\prime \prime}$ E). A colony was picked from $1 / 10$-strength marine agar 2216 (Difco) after incubation for 1 month at $25{ }^{\circ} \mathrm{C}$ and was subcultured on marine agar 2216 (MA; Difco).

Biomass for the study of biochemical and chemotaxonomic characteristics was prepared by culturing cells in tryptic soy

Abbreviation: $\mathrm{A}_{2} \mathrm{pm}$, diaminopimelic acid.

The GenBank/EMBL/DDBJ accession number for the 16S rRNA gene sequence of strain $\mathrm{HG} 667^{\top}$ is $\mathrm{AB} 286025$. broth (Difco) at $27{ }^{\circ} \mathrm{C}$ for 3 or 4 days and then harvesting them by centrifugation.

The cell morphology of the strain was studied with a light microscope during growth (at $21 \mathrm{~h}$ and at 2, 3, 4 and 5 days) in marine broth at $27^{\circ} \mathrm{C}$. Bacterial cells (3-day-old culture on MA) were also studied with a scanning electron microscope (model JSM-5600; JEOL). Motility was investigated using microscopic analysis. Colonies were suspended in artificial seawater (Lyman \& Fleming, 1940) after incubation for 3 days, 1 week and 1 month at $27^{\circ} \mathrm{C}$ on MA medium. $\mathrm{NaCl}$ tolerance was determined on $1 / 5$ strength nutrient agar and $\mathrm{pH}$ and temperature ranges for growth were determined on MA. The ability of the strain to grow on various substrates serving as sole carbon sources (at $1 \%, w / v)$ was determined using a carbon-utilization medium (Pridham \& Gottlieb, 1948) (Nihon Pharmaceutical). The isolate was characterized biochemically using API ZYM (bioMérieux) in accordance with the manufacturer's instructions.

Whole-cell hydrolysates were analysed for $\mathrm{A}_{2} \mathrm{pm}$ isomers by using TLC (Becker et al., 1965; Hasegawa et al., 1983). Purified cell walls were obtained using the method of Kawamoto et al. (1981). Purified cell wall $(1 \mathrm{mg}$ ) was hydrolysed at $100{ }^{\circ} \mathrm{C}$ with $1 \mathrm{ml} 6 \mathrm{M} \mathrm{HCl}$ for $16 \mathrm{~h}$. The residue was dissolved in $100 \mu \mathrm{l}$ water and then used for amino acid analysis by TLC. Sugars in the purified cell wall 
were determined according to the procedures described by Staneck \& Roberts (1974). The presence of mycolic acid was checked using the TLC method of Tomiyasu (1982). Menaquinones were extracted and purified using the method of Collins et al. (1977) and then analysed by HPLC (model 802-SC; Jasco) on a chromatograph equipped with a Capcell Pak C18 column (Shiseido) (Tamaoka et al., 1983). Polar lipids were extracted according to the method described by Minnikin et al. (1984). The two-dimensional TLC method (Komagata \& Suzuki, 1987) was used to determine the phospholipid profile. To determine the cellular fatty acid methyl esters, cell mass of strain $\mathrm{HG}_{66} 7^{\mathrm{T}}$ was harvested from TSA plates after cultivation for 3 days at $30{ }^{\circ} \mathrm{C}$ and subjected to analysis using GLC (model HP6890; Hewlett Packard). The method described in the manual (version 6) of the Sherlock Microbial Identification System (version 5.0) (MIDI) was used for sample preparation and analysis.

To determine the $\mathrm{G}+\mathrm{C}$ content, chromosomal DNA was isolated as described by Saito \& Miura (1963) and the content estimated using HPLC (Tamaoka \& Komagata, 1984).

DNA for 16S rRNA gene sequence analysis was prepared using an InstaGene matrix (Bio-Rad). The 16S rRNA gene was amplified by using the PCR with a forward primer corresponding to positions $8-27$ and a reverse primer corresponding to positions 1492-1510 (Escherichia coli numbering system; Weisburg et al., 1991) and sequenced using an automatic sequence analyser (3730 DNA analyser; Applied Biosystems) with the BigDye Terminator v3.1 cycle sequencing kit (Applied Biosystems). Species related to the novel strain were identified by performing sequence database searches with BLAST (Altschul et al., 1990). Sequence data for related species were retrieved from GenBank and used for a detailed phylogenetic analysis. The phylogenetic analysis was performed using CLUSTAL $\mathrm{W}$ software (Thompson et al., 1994). Nucleotide substitution rates ( $K_{\text {nuc }}$ values) were calculated (Kimura \& Ohta, 1972) and phylogenetic trees were constructed using the neighbour-joining method as described by Saitou \& Nei (1987). The DNAML program in the PHYLIP $3.5 \mathrm{c}$ package (Felsenstein, 1985) was used for maximum-likelihood analysis, with a default transition/transversion ratio of 2.000000. Sequence similarity values were determined by means of visual comparison and manual calculation.

The cells of strain $\mathrm{HG}_{66} 7^{\mathrm{T}}$ were aerobic, Gram-positive, non-spore-forming, irregular short rods or cocci (Fig. 1). Observation using light microscopy showed that the cells occur singly and also in pairs, short chains or clumps. No distinct life cycle and no changes in cell morphology were observed under the light microscope during growth (for $21 \mathrm{~h}$ to 5 days) in marine broth. Motility was not observed under the conditions used. The DNA G $+\mathrm{C}$ content of the strain was $70 \mathrm{~mol} \%$. The cell wall contained meso- $\mathrm{A}_{2} \mathrm{pm}$ as the diagnostic diamino acid. The cell-wall sugars were galactose, glucose and ribose. The major menaquinone (constituting about $90 \%$ ) was MK- $8\left(\mathrm{H}_{4}\right)$. The phospho-

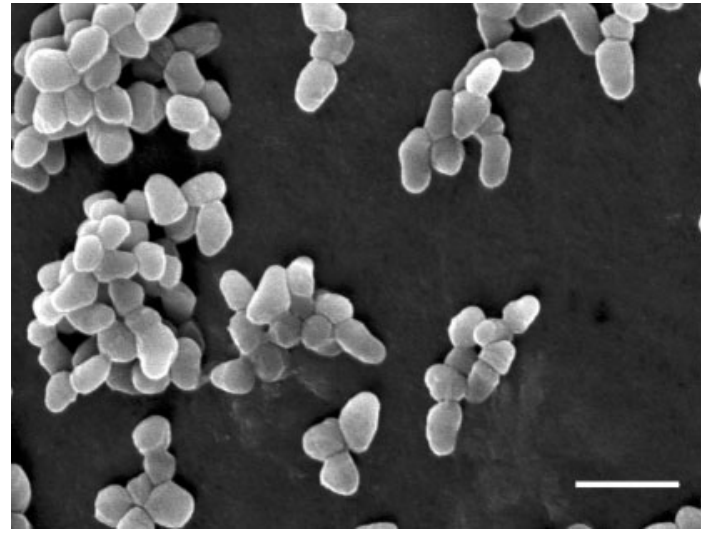

Fig. 1. Scanning electron micrograph of cells from a 3-day-old culture of strain $\mathrm{HG} 667^{\top}$ grown on MA medium at $27^{\circ} \mathrm{C}$. Bar, $2 \mu \mathrm{m}$.

lipids were phosphatidylglycerol, an unknown phospholipid, diphosphatidylglycerol and phosphatidylinositol mannosides. The cellular fatty acids were iso- $\mathrm{C}_{17: 0}(38.5 \%)$, $\mathrm{C}_{17: 1} \omega 8 c(19.3 \%), \mathrm{C}_{18: 1} \omega 9 c(10.5 \%)$, iso- $\mathrm{C}_{15: 0}(7.4 \%)$, iso- $\mathrm{C}_{17: 1} \omega 9 c(5.2 \%), \mathrm{C}_{16: 0}(3.0 \%), \mathrm{C}_{17: 0}(2.7 \%), \mathrm{C}_{18: 1} \omega 7 c$ $(1.7 \%)$, iso- $\mathrm{C}_{16: 0}(1.1 \%)$ and anteiso- $\mathrm{C}_{17: 0}(1.1 \%)$.

To determine the phylogenetic position of strain $\mathrm{HG}_{6} 67^{\mathrm{T}}$, an almost-complete $16 \mathrm{~S}$ rRNA gene sequence was determined. A database search demonstrated that the strain belonged to the family Intrasporangiaceae in the suborder Micrococcineae. Phylogenetic analysis based on 16S rRNA gene sequences showed that strain $\mathrm{HG}_{667}{ }^{\mathrm{T}}$ (1435 bp) was closely related to Kribbia dieselivorans $\mathrm{N}_{113^{\mathrm{T}}}$ (1476 bp), with $96.0 \%$ similarity (Fig. 2). The $16 \mathrm{~S}$ rRNA gene sequence identities of $\mathrm{HG}_{667}{ }^{\mathrm{T}}$ with respect to type strains of type species of other genera with meso- $\mathrm{A}_{2} \mathrm{pm}$ in the cell wall were as follows: $94.9 \%$ with Janibacter limosus DSM $11140^{\mathrm{T}}(1473 \mathrm{bp}), 94.8 \%$ with Knoellia sinensis DSM $12331^{\mathrm{T}}(1479 \mathrm{bp}), 92.8 \%$ with Oryzihumus leptocrescens KV-628 ${ }^{\mathrm{T}}$ (1429 bp), 93.4\% with Phycicoccus jejuensis KSW2-15 ${ }^{\mathrm{T}}$ (1413 bp) and $93.0 \%$ with Tetrasphaera japonica ACM 5116 ${ }^{\mathrm{T}}$ (1445 bp).

Strain $\mathrm{HG}_{667}^{\mathrm{T}}$ can be differentiated from other genera of the family Intrasporangiaceae on the basis of its cell-wall diamino acid, cell morphology and major fatty acid composition. Table 1 shows the phenotypic characteristics of the isolate and of meso- $\mathrm{A}_{2} \mathrm{pm}$-containing members of the family Intrasporangiaceae. The phylogenetically closest genus is Kribbia, members of which also contain meso$\mathrm{A}_{2} \mathrm{pm}$. Strain $\mathrm{HG}_{667}{ }^{\mathrm{T}}$ can be differentiated from the genus Kribbia on the basis of major fatty acids and growth temperature. While strains of the genus Kribbia can grow over a wide range of temperatures $\left(8-42{ }^{\circ} \mathrm{C}\right)$, strain $\mathrm{HG} 67^{\mathrm{T}}$ grows at $18-34{ }^{\circ} \mathrm{C}$. Strain $\mathrm{HG} 67^{\mathrm{T}}$ can be differentiated from the genera Janibacter, Knoellia, Tetrasphaera and Phycicoccus on the basis of cell morphology and the pattern of phospholipids. The differential 


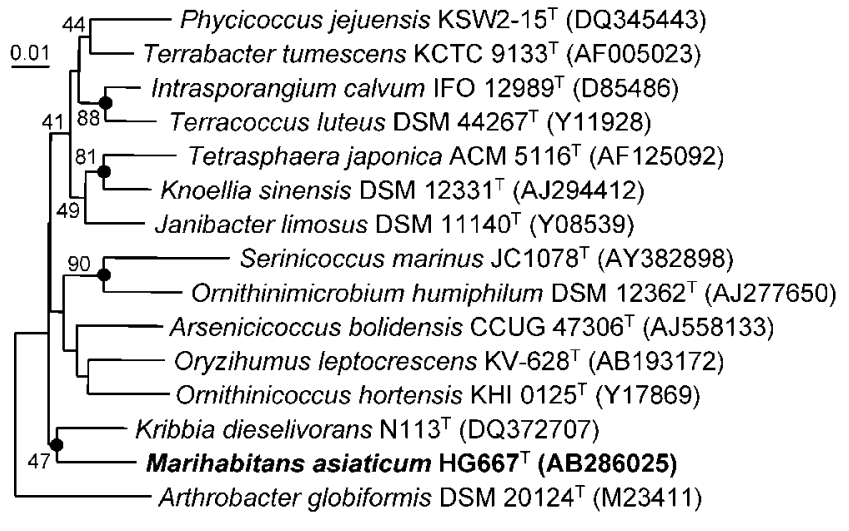

Fig. 2. Neighbour-joining phylogenetic tree, based on $16 \mathrm{~S}$ rRNA gene sequences, for strain $\mathrm{HG} 667^{\top}$ and members of the family Intrasporangiaceae. Only values with greater than $40 \%$ significance are shown. Filled circles indicate that the corresponding nodes were also recovered in the maximum-likelihood tree. The tree was unrooted and Arthrobacter globiformis DSM $20124^{\top}$ was used as an outgroup. Bar, $0.01 K_{\text {nuc }}$.

characteristic between strain $\mathrm{HG}_{6} 67^{\mathrm{T}}$ and the genus Oryzihumus is cell morphology. Other characteristics of strain $\mathrm{HG}_{667}{ }^{\mathrm{T}}$ are given in the genus and species descriptions.

On the basis of the data presented here, we consider that strain $\mathrm{HG}_{667}{ }^{\mathrm{T}}$ merits description as a novel genus and species within the family Intrasporangiaceae, for which the name Marihabitans asiaticum gen. nov., sp. nov. is proposed.

\section{Description of Marihabitans gen. nov.}

Marihabitans (Ma.ri.ha'bi.tans. L. neut. n. mare sea; L. part. adj. habitans inhabiting; N.L. adj. used as a neut. subst. Marihabitans inhabitant of the sea).

Cells are Gram-positive, non-motile, non-spore-forming, catalase-positive, aerobic, irregular short rods and cocci. The peptidoglycan is of the A type and contains meso$\mathrm{A}_{2} \mathrm{pm}$, alanine and glutamic acid. The cell-wall sugars are galactose, glucose and ribose. Mycolic acids are absent. The major menaquinone is $\mathrm{MK}-8\left(\mathrm{H}_{4}\right)$. The phospholipids comprise phosphatidylglycerol, an unknown phospholipid, diphosphatidylglycerol and phosphatidylinositol mannosides. The cellular fatty acids are a complex mixture of straight-chain saturated, monounsaturated and iso- and anteiso-methyl-branched acids and consist mainly of isomethyl-branched saturated and straight-chain monounsaturated acids, with iso- $\mathrm{C}_{17: 0} \mathrm{C}_{17: 1} \omega 8 c$ and $\mathrm{C}_{18: 1} \omega 9 c$ predominating. Phylogenetically, the genus is a member of the family Intrasporangiaceae, suborder Micrococcineae. The type species is Marihabitans asiaticum.

\section{Description of Marihabitans asiaticum sp. nov.}

Marihabitans asiaticum (a.si.a'ti.cum. N.L. neut. adj. asiaticum of Asia, the source of the type strain).

Displays the properties of the genus with the following additions. Cells are $0.6-1.0 \mu \mathrm{m}$ wide and $0.8-1.3 \mu \mathrm{m}$ long. Colonies are light yellow. Growth occurs between 18 and $34{ }^{\circ} \mathrm{C}$. The optimum $\mathrm{pH}$ for growth is 9 on MA. On $1 / 5$ strength nutrient agar, $\mathrm{NaCl}$ is tolerated at concentrations up to $7 \%$. Positive for nitrate reduction and hydrolysis of

Table 1. Differential characteristics of strain $\mathrm{HG} 667^{\top}$ and meso- $\mathrm{A}_{2} \mathrm{pm}$-containing members of the family Intrasporangiaceae

Data for reference genera were taken from Jung et al. (2006) (Kribbia), Martin et al. (1997), Lang et al. (2003) and Yoon et al. (2004) (Janibacter), Groth et al. (2002) (Knoellia), Kageyama et al. (2005) (Oryzihumus), Lee (2006) (Phycicoccus) and Maszenan et al. (2000) and Hanada et al. (2002) (Tetrasphaera). ND, No data available.

\begin{tabular}{|c|c|c|c|c|}
\hline Taxon & Cell morphology & Major fatty acids* & Polar lipids $\dagger$ & $\begin{array}{c}\text { DNA G+C } \\
\text { content }(\mathrm{mol} \%)\end{array}$ \\
\hline Strain $\mathrm{HG} 67^{\mathrm{T}}$ & Irregular short rods and cocci & $\mathrm{i}-\mathrm{C}_{17: 0}, \mathrm{C}_{17: 1} \omega 8 c, \mathrm{C}_{18: 1} \omega 9 c$ & DPG, PG, PL, PIMs & 70 \\
\hline Kribbia & Irregular short rods or cocci & $\begin{array}{c}\text { 10-Methyl } \mathrm{C}_{18: 0}, \mathrm{i}-\mathrm{C}_{16: 0}, \mathrm{C}_{18: 1} \omega 9 c \text {, } \\
\mathrm{C}_{16: 0}, \mathrm{C}_{18: 0}\end{array}$ & $\mathrm{ND}$ & $69-70$ \\
\hline Janibacter & Coccoid to rod-shaped & $\mathrm{i}-\mathrm{C}_{16: 0}, \mathrm{C}_{17: 1} \omega 8 c, \mathrm{C}_{18: 1} \omega 9 c, \mathrm{C}_{17: 0}$ & DPG, PG, PI & $69-73$ \\
\hline Knoellia & Irregular rods and cocci & $\mathrm{i}-\mathrm{C}_{15: 0}, \mathrm{i}-\mathrm{C}_{17: 0}, \mathrm{i}-\mathrm{C}_{16: 0}$, ai- $\mathrm{C}_{17: 0}$ & DPG, PE, PI, PG, PL & $68-69$ \\
\hline Oryzihumus & Irregular rods & $\mathrm{i}-\mathrm{C}_{16: 0}, \mathrm{i}-\mathrm{C}_{15: 0}, \mathrm{i}-\mathrm{C}_{14: 0}$ & $\mathrm{ND}$ & $72-73$ \\
\hline Phycicoccus & Cocci & $\mathrm{C}_{17: 1} \omega 8 c, \mathrm{i}-\mathrm{C}_{16: 0}, \mathrm{i}-\mathrm{C}_{15: 0}$ & DPG, PE, PI & 74 \\
\hline Tetrasphaera & Cocci or short rods & $\begin{array}{l}\text { ai- } \mathrm{C}_{15: 0} \text { and } \mathrm{i}-\mathrm{C}_{15: 0},{ }^{a} \mathrm{i}-\mathrm{C}_{16: 0}, \text { ai- } \mathrm{C}_{17: 0} \\
\text { and } \mathrm{i}-\mathrm{C}_{15: 0}{ }^{b} \text { or } \mathrm{i}-\mathrm{C}_{16: 0} \text { and ai- } \mathrm{C}_{17: 0} c_{\ddagger}\end{array}$ & DPG, PG, PI, PES, PLS & $68-71$ \\
\hline
\end{tabular}

${ }^{*}$ Major fatty acids are defined as constituting $>10 \%$ of the total fatty acid content. ai, Anteiso; i, iso.

$\nmid$ DPG, Diphosphatidylglycerol; PE, phosphatidylethanolamine; PG, phosphatidylglycerol; PI, phosphatidylinositol; PL, unknown phospholipid(s); PIMs, phosphatidylinositol mannosides.

\$Data for: $a$, T. elongata; $b, T$. australiensis; $c$, T. japonica.

$\S$ Detected in only some representatives of the genus. 
casein and gelatin. Negative for urease activity, starch hydrolysis and oxidase activity. D-Galactose, D-glucose and trehalose are assimilated, but L-arabinose, D-fructose, maltose, D-mannitol, D-mannose, raffinose, L-rhamnose, sucrose and D-xylose are not assimilated. Esterase (C4), esterase lipase (C8), leucine arylamidase, cystine arylamidase, acid phosphatase, $\alpha$-glucosidase and $\beta$-glucosidase are detected in the API ZYM enzyme assay; tests for alkaline phosphatase, lipase (C14), valine arylamidase, trypsin, chymotrypsin, $\alpha$-galactosidase, $\beta$-galactosidase, $\beta$-glucuronidase, $N$-acetyl- $\beta$-glucosaminidase, $\alpha$-mannosidase and $\alpha$ fucosidase are negative. Weakly positive for naphthol-ASBI-phosphohydrolase. The DNA G + C content of the type strain is $70 \mathrm{~mol} \%$.

The type strain, $\mathrm{HG}_{667}^{\mathrm{T}}\left(=\mathrm{MBIC} 07497^{\mathrm{T}}=\mathrm{DSM} 18935^{\mathrm{T}}\right)$, was isolated from surface seawater collected at the Kesennuma ferry port in Miyagi Prefecture, Japan.

\section{Acknowledgements}

This study was supported, in part, by a grant from the 21st Century COE Program of the Ministry of Education, Culture, Sports, Science and Technology (MEXT), by a JSPS Grant-in-Aid for Science Research and by the New Energy and Industrial Technology Development Organization (NEDO).

\section{References}

Altschul, S. F., Gish, W., Miller, W., Myers, E. W. \& Lipman, D. J. (1990). Basic local alignment search tool. J Mol Biol 215, 403-410.

Becker, B., Lechevalier, M. P. \& Lechevalier, H. A. (1965). Chemical composition of cell-wall preparation from strains of various formgenera of aerobic actinomycetes. Appl Microbiol 13, 236-243.

Collins, M. D., Pirouz, T., Goodfellow, M. \& Minnikin, D. E. (1977). Distribution of menaquinones in actinomycetes and corynebacteria. J Gen Microbiol 100, 221-230.

Felsenstein, J. (1985). Confidence limits on phylogenies: an approach using the bootstrap. Evolution 39, 783-791.

Groth, I., Schumann, P., Schuetze, B., Augsten, K., Kramer, I. \& Stackebrandt, E. (2002). Knoellia sinensis gen. nov., sp. nov. and Knoellia subterranea sp. nov., two novel actinobacteria isolated from a cave. Int J Syst Evol Microbiol 52, 77-84.

Hanada, S., Liu, W.-T., Shintani, T., Kamagata, Y. \& Nakamura, K. (2002). Tetrasphaera elongata sp. nov., a polyphosphate-accumulating bacterium isolated from activated sludge. Int J Syst Evol Microbiol 52, 883-887.

Hasegawa, T., Takizawa, M. \& Tanida, S. (1983). A rapid analysis for chemical grouping of aerobic actinomycetes. J Gen Appl Microbiol 29, 319-322.

Jung, S.-Y., Kim, H.-S., Song, J. J., Lee, S.-G., Oh, T.-K. \& Yoon, J.-H. (2006). Kribbia dieselivorans gen. nov., sp. nov., a novel member of the family Intrasporangiaceae. Int J Syst Evol Microbiol 56, 2427-2432.

Kageyama, A., Takahashi, Y., Seki, T., Tomoda, H. \& Ōmura, S. (2005). Oryzihumus leptocrescens gen. nov., sp. nov. Int J Syst Evol Microbiol 55, 2555-2559.

Kawamoto, I., Oka, T. \& Nara, T. (1981). Cell wall composition of Micromonospora olivoasterospora, Micromonospora sagamiensis, and related organisms. J Bacteriol 146, 527-534.
Kimura, M. \& Ohta, T. (1972). On the stochastic model for estimation of mutation distance between homologous proteins. J Mol Evol 2, 87-90.

Komagata, K. \& Suzuki, K. (1987). Lipid and cell-wall analysis in bacterial systematics. Methods Microbiol 19, 161-207.

Lang, E., Kroppenstedt, R. M., Swiderski, J., Schumann, P., Ludwig, W., Schmid, A. \& Weiss, N. (2003). Emended description of Janibacter terrae, including ten dibenzofuran-degrading strains and Janibacter brevis as its later heterotypic synonym. Int J Syst Evol Microbiol 53, 1999-2005.

Lee, S. D. (2006). Phycicoccus jejuensis gen. nov., sp. nov., an actinomycete isolated from seaweed. Int J Syst Evol Microbiol 56, 2369-2373.

Lyman, J. \& Fleming, R. H. (1940). Composition of sea water. J Mar Res 3, 134-146.

Martin, K., Schumann, P., Rainey, F. A., Schuetze, B. \& Groth, I. (1997). Janibacter limosus gen. nov., sp. nov., a new actinomycete with mesodiaminopimelic acid in the cell wall. Int J Syst Bacteriol 47, 529-534.

Maszenan, A. M., Seviour, R. J., Patel, B. K. C., Schumann, P., Burghardt, J., Tokiwa, Y. \& Stratton, H. M. (2000). Three isolates of novel polyphosphate-accumulating Gram-positive cocci, obtained from activated sludge, belong to a new genus, Tetrasphaera gen. nov., and description of two new species, Tetrasphaera japonica sp. nov. and Tetrasphaera australiensis sp. nov. Int J Syst Evol Microbiol 50, 593-603.

Minnikin, D. E., O'Donnell, A. G., Goodfellow, M., Alderson, G., Athalye, M., Schaal, A. \& Parlett, J. H. (1984). An integrated procedure for the extraction of bacterial isoprenoid quinones and polar lipids. J Microbiol Methods 2, 233-241.

Pridham, T. G. \& Gottlieb, D. (1948). The utilization of carbon compounds by some Actinomycetales as an aid for species determination. J Bacteriol 56, 107-114.

Saito, H. \& Miura, K. (1963). Preparation of transforming deoxyribonucleic acid by phenol treatment. Biochim Biophys Acta 72, 619-629.

Saitou, N. \& Nei, M. (1987). The neighbor-joining method: a new method for reconstructing phylogenetic trees. Mol Biol Evol 4, 406-425.

Stackebrandt, E. \& Schumann, P. (2000). Description of Bogoriellaceae fam. nov., Dermacoccaceae fam. nov., Rarobacteraceae fam. nov. and Sanguibacteraceae fam. nov. and emendation of some families of the suborder Micrococcineae. Int J Syst Evol Microbiol 50, 1279-1285.

Stackebrandt, E., Rainey, F. A. \& Ward-Rainey, N. L. (1997). Proposal for a new hierarchic classification system, Actinobacteria classis nov. Int J Syst Bacteriol 47, 479-491.

Staneck, J. L. \& Roberts, G. D. (1974). Simplified approach to identification of aerobic Actinomycetes by thin-layer chromatography. Appl Microbiol 28, 226-231.

Tamaoka, J. \& Komagata, K. (1984). Determination of DNA base composition by reversed-phase high-performance liquid chromatography. FEMS Microbiol Lett 25, 125-128.

Tamaoka, J., Katayama-Fujimura, Y. \& Kuraishi, H. (1983). Analysis of bacterial menaquinone mixtures by high performance liquid chromatography. J Appl Bacteriol 54, 31-36.

Thompson, J. D., Higgins, D. G. \& Gibson, T. J. (1994). CLUSTAL W: improving the sensitivity of progressive multiple sequence alignment through sequence weighting, position-specific gap penalties and weight matrix choice. Nucleic Acids Res 22, 4673-4680.

Tomiyasu, I. (1982). Mycolic acid composition and thermally adaptative changes in Nocardia asteroides. J Bacteriol 151, 828-837.

Weisburg, W. G., Barns, S. M., Pelletier, D. A. \& Lane, D. J. (1991). 16 S ribosomal DNA amplification for phylogenetic study. J Bacteriol 173, 697-703.

Yoon, J. H., Lee, H. B., Yeo, S. H. \& Choi, J. E. (2004). Janibacter melonis sp. nov., isolated from abnormally spoiled oriental melon in Korea. Int J Syst Evol Microbiol 54, 1975-1980. 